\title{
Difficulties of English Language Teaching in Bangladesh
}

\author{
Ismail Akbas \\ English Language Teacher, Int'1 Turkish Hope School \\ House: 87, Road: 24, Gulshan 2, Dhaka 1212, Bangladesh \\ Tel: 880-176-260-5600Ｅ-mail: bengal.ismail@gmail.com
}

Received: May 10, 2015 Accepted: November 10, 2015 Published: November 15, 2015

doi:10.5296/ijele.v4i1.8575 URL: http://dx.doi.org/10.5296/ijele.v4i1.8:575

\begin{abstract}
Identifying the difficulties of English Language Teaching at English Medium Schools' Primary levels are essential in Bangladesh to achieve to set English language competencies in the educational institutions. The main purpose of this study was to discover the specific problems of English Language Teaching at English Medium Schools' Primary levels. The current study was a qualitative research technique by nature. One set of closed-ended questionnaires were used to collect data from the teachers who live within three cities to understand the views and situation of the difficulties of English Language teaching. The study indicates that teachers, students and school administration encounter several problems due to lack of skilled teachers, proper teacher training, using proper teaching methods and materials, physical facilities and so on. As a result, English curriculum implementation at the primary level in Bangladesh is becoming unsuccessful in most of the schools; however there are several adequately designed buildings with well trained teachers along with proper educational materials. Given that the number of schools is in the thousands, we shall draw comparisons between respective educational institutions.
\end{abstract}

Keywords: Teacher, school, education, difficulty, English Language 


\section{Introduction}

Whenever children initially acquire knowledge of a new foreign language, their response to the newly introduced language is different; principally, the only reason, more or less, is that it is dissimilar to their native language. A foreign language has very habitually unalike syntax, rules, structures, system etc. Some students effortlessly deal with the language, while some require greater efforts to do so and some struggle with it from the very beginning.

In the name of globalization, it is essential to learn foreign languages and thus the administrators keep foreign languages on the school curriculum. Usually, foreign languages are taught at the preschools in the South Asian countries although there are some national curriculum schools where the local curriculum is taught in English.

The case for teaching English language is different in English Medium Schools' primary sections. In these types of schools in Bangladesh, Bangladeshi students learn all the subjects with the implementation of English only. In Bangla Medium Schools, there are customary difficulties, however in English Medium Schools, we observe language related complications.

The purpose of this study is to identify the difficulties faced by the teachers who teach at English Medium Schools' Primary Sections in Bangladesh. In order to identify this, I needed to find the results of demographic analysis, challenges and problems, lack of support due to financial issues or ignorance, difficulties in understanding the nature of language teaching, heavy workload of the teacher and more.

\section{Literature Review}

The main purpose of using language to communicate one's feelings, thoughts, needs, necessities and ideas to others is (Banu, 2009). Experimental studies show that many of the primary graduates are failing to learn language skills that they can use efficiently (Ahmed \& Nath, 2005). To learn language, comprehension strategies need to be more explicitly discussed and individual interpretation of texts need to be valued inside the classroom. Children need to learn different reading strategies, for example, scanning, skimming, and locating information throughout the text to solve different reading problems. All learning experiences do not necessarily lead to learning, unless subsequent opportunities for reflection, application, correlation and consolidation are created (Shukla, 2008).

Motivation is perhaps the greatest factor: 'Let us say that, given motivation, it is inevitable that a human being will learn a second language if he is exposed to the language data.' (Corder, 1967) Exigency of teaching English in the South Asian subcontinent was discussed first time in Lord Macaulay's minute of 1835 (Krishnaswamy \& Sriraman, 1984). The prominence and helpfulness of the education that would be given to the matives through the medium of English was stated by Macaulay in his Minutes. Mr. Macaulay revealed two goals of such education. The first was to create a class of natives who despite their blood and color through this education; would be English in culture and be able to "interpret" between the rulers and the subjects. The second was to create a "demand" for the European institutions. Clearly both the objectives were designed to serve the interest of the Masters, not of the 
subjects. When it published, he said, "it will be the proudest day in English history" (Sadek, 2002)

In Bangladesh, during the Pakistani period, English was a second language as an inheritance of British rule. The educated or even fairly educated people had to use English in offices, profession, education and other purposes. However, after the war of liberation in 1971, in independent Bangladesh, the official status of the English language changed to a foreign language. In this monolingual country people do almost everything in Bengali and did not use English in real life communication. They started facing problems when they were required to communicate in English. Moreover, recently the EFL situation in post liberation Bangladesh, English has regained an important unofficial status. English is used in many government, semi-government and private organizations along with Bengali (Ainy, 2001).

Gorman (1968) assessed the importance of proficiency in English for social mobility and the role of educational provision in attaining proficiency in English in a multilingual environment. Clegg and Afitska (2011) show how a lack of fluency in a common language leads to 'creative bilingual practices' in order to enable communication between teachers and learners in African classrooms.

Shin \& Koh, 2007, described that student misconducts have interfered with a constructive learning environment to manage student behavior for primary concern of teachers. From the days observing the classes as intern, teachers generally express their worry about supervising the students and creating a well-organized milieu so as to produce a proper atmosphere for learning; and classroom management is usually mentioned as the most complicated aspect of teaching. Doyle (1986) also states that upholding order in a classroom is an elementary task of schooling as management activities lead to the founding and upkeep of those conditions in which teaching can take place efficiently and professionally. There is accumulating evidence from meta-analyses of variables that effect school culture and that classroom management has been acknowledged as one of the variables that has utmost inspiration on school education (Freiberg, 1999). Nowadays, classroom management is turming out to be an accumulative problem for teachers and administrators in primary schools because of changes in educational surroundings.

Éireann (2004) states that a distinctive issue for primary school teachers in addressing children's language development in the mother tongue is the relationship between language and its disadvantage. In the early $1960 \mathrm{~s}$, Basil Bernstein, a British sociologist, became well known for his view that the relationship between school performance and socio-economic background could be explained in terms of variations in the forms of language found in different social classes [Bernstein, 1960, 1961 and 1970]. He is best known for coining the terms 'elaborated code' and 'restricted code' in relation to the way language is used and structured in different social groups.

Ganakumaran (2003), the reading material used in this programme includes especially those that are contemporary, mostly written in the 1990s, appeal to young learners, about children and their adventures, and those that tap into the learners' imaginative potential. Fry (2007) cited that literature brings the child into an encounter with language in its most complex and 
varied forms. Lewen (2005) states that, this will familiarize the students to the different types of genres in the English Language syllabus that needs to be covered. Each type of genres have its' own values and purpose which have the connection with the students interactions in their real-life situation. This will enable the students to function in the society they are in when they are going out and perform later. Gorman (1968) weighed the significance of proficiency in English for the role of educational provision and social mobility in attaining proficiency in English in a multilingual environment.

Kizildag (2009) mentioned in her study that, the trend in motivation research has been replaced with detailed lists of teachers' practices rather than what motivates learners. As for the motivation and interest of the students, we know that motivation is one of the key components to success for language teachers (Dörnyei, 2001; Ellis, 1994). Teachers often believe that their job is to motivate students by creating classroom tasks that are interesting and engaging and by using authentic materials to stimulate further interest in the target language, as Winke (2005) states.

Classroom resources must be adequate enough to provide learners with the skills needed to be competent in language learning. According to Driscoll and Frost (1999), language competence grows incrementally through the interaction of reading, writing and talking. Sharpe (2001) concurs, noting that with "a range of resources and employing extravagant gestures, vivid actions and animated facial expression, the teacher communicates to the children the imaginary L2 context and introduces the appropriate language items" (p. 154). Classroom resources are thus crucial and must be able to be accessed by all learners in a class rather than shared. Small class size is likewise important because it improves and maintains good teacher-pupil relationships. It increases a teacher's knowledge of each child's needs and monitoring their learning becomes easy. Computer utilization and radio lessons also enhance language teaching and learning. In this context, the Internet is described as "a dynamic, ever changing source of ideas and materials for teachers and resources for use with pupils" (Cajkler \& Addelman, 2000, p. 176).

Glynis (1999) stated that the teachers need a clear framework. They need models for pronunciation, a scheme of work and teaching ideas. Emphasis should be on the important mathematical and number-related work. Many children can count in sequence but are unable to manipulate the mathematics and need a great deal of practice. It is sometimes not appreciated by language specialists that, for the majority of children, honing of mathematical skills is still very important. With practice, children can calculate as quickly in L2 and in L1 calculate as quickly in L2 and in L1.

\section{Methodology}

This study used qualitative research technique; creating and providing the best possible learning experience for the students or participants is the focus of instructional design and teaching activities. This focus is qualitative in that it looks for indicators of success or improvement through the experiences and stories of the participants (Borg 2003).

The research questions examined what works better in primary school teachers' classroom 


\section{Macrothink}

management approaches at English medium schools among Bangladeshi students in Bangladesh that may be more appropriately examined through qualitative methods than quantitative.

Moreover, literature [Ahmed, M. \& Nath, S. R. (2005), Ainy, S. (2001), Banu, L. F. A. (2009), Hasan, M. K. (2004), Karim, K. M. R. (2004)] divulges that in Bangladesh with the initiation of constructivism in education, the outlook of teaching spaces has been rehabilitated as well as the requirements of the schoolchildren and instructors. Therefore; the prerequisite for adaptation of schoolroom supervision methods of educators to generate a constructivist education setting was recognized.

\subsection{Research Questions}

- What are the views of primary school teachers on subject specialization education?

- What are the administrator related problems of Primary Teachers at English Medium Schools?

- To what extent is the content proficiency of teachers as generalists developed in schools?

- What is the necessity for new teachers for their professional development?

\subsection{Development of the Questionnaire}

Marshall (1998) said "questionnaires can help you collect information about what people do, what they have, what they think, know, feel or want." She also categorized the data in different types, as:

- knowledge - what people know; how well they understand something.

- belief - what people think is true; an opinion.

- attitude - how people feel about something; a preference.

- behavior - what people do - may be a physical/manual or mental behavior.

- attributes - what people are; what people have."

I have administered a closed-ended questionnaire to collect data on the difficulties of English language teaching at English medium schools 'primary sections in Bangladesh for this study. The questionnaire was very useful tool for gathering information in face-to-face settings. It assists in accomplishing the research objectives.

For the purpose of developing the questionnaire, the literature related to difficulties of English language teaching in accordance with the principles of constructivism was reviewed. 


\begin{tabular}{|c|c|c|c|c|c|c|}
\hline & & 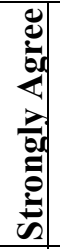 & 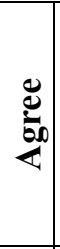 & & 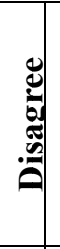 & 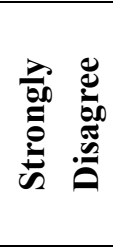 \\
\hline 1 & I am burdened by curricular freedom. & & & & & \\
\hline 2 & My students' parents criticize me in front of my students. & & & & & \\
\hline 3 & Family background has effect in English Language teaching. & & & & & \\
\hline 4 & The administrators in my school have background in education. & & & & & \\
\hline 5 & We have proper library in our school with English Language materials. & & & & & \\
\hline 6 & $\begin{array}{l}\text { We have proper multimedia room in our school with English Language } \\
\text { materials. }\end{array}$ & & & & & \\
\hline 7 & The house tutors of my students are misleading them. & & & & & \\
\hline 8 & The administrators organize proper admission exam for placement. & & & & & \\
\hline 9 & $\begin{array}{l}\text { There is properly maintained suspension \& expulsion system in my } \\
\text { school. }\end{array}$ & & & & & \\
\hline 10 & My students' parents have overprotective attitude. & & & & & \\
\hline 11 & There is well-designed playground in my school. & & & & & \\
\hline 12 & I have unsupportive environments in my school. & & & & & \\
\hline 13 & I am struggling with classroom management problem. & & & & & \\
\hline 14 & $\begin{array}{l}\text { I think student's mental abilities have effect on English Language } \\
\text { teaching. }\end{array}$ & & & & & \\
\hline 15 & I think there are resource problems in my school. & & & & & \\
\hline 16 & I'm underpaid. & & & & & \\
\hline 17 & I'm untrained. & & & & & \\
\hline
\end{tabular}

The questionnaire was based on 17 statements. They covered important point for the difficulties of teaching English language at English medium schools' primary sections in Bangladesh. For the placement of the statements no systematic order was followed, rather the statements were placed in random order, and below the statement there was a grid consisting of five columns: for 'strongly agree', 'agree', 'uncertain', 'disagree' and 'strongly agree'. The participants were asked to put a tick mark in the appropriate option in order to show how far they agreed or disagreed with each statement. The findings were shown in the 'Result' part in charts.

The population of this study included the teachers working in the private primary schools in Dhaka, Chittagong and Bogra in November 2014. From the list of 109 English medium schools 


\section{MInstitute Macrothink $_{\text {Int }}$}

from internet, 28 of them were selected with consideration of convenience. Selection was based on the student density of the schools with more number of teachers. Out of 28 schools, 25 principals allowed me to distribute the questionnaire. A written permission was received from the school headmasters and volunteer participants were selected for partaking in the survey. Then all of the teachers were given the closed-ended questionnaires. The participants consisted of 328 teachers from different schools and branches.

I deem the questionnaire valid and reliable as because I have personally visited the schools in Dhaka, where I live, and travelled to Bogra and Chittagong cities to provide the reliability. The participant teachers completed the questionnaire in front of me and one of the representatives from the school management. Another important matter for validity and reliability is, people in Bangladesh are so humble and objective that they'll be very truthful when answering the questionnaire. Although some questions were related with personal experience or the institution where they serve, they understood that their participation was for a greater purpose.

Descriptive statistics were employed to present the background characteristics of the respondents. Regarding gender distribution of the teachers in this study, $73.2 \%$ of them were females while 26.8 were males.

Table 1. Participants' Age and Experience

\begin{tabular}{|l|l|l|l|l|l|l|l|l|l|}
\hline \multicolumn{3}{|c|}{ Age } & \multicolumn{7}{c|}{ Experience } \\
\hline $22-35$ & $36-46$ & $47-56$ & $56-$ & $1-5$ & $6-10$ & $11-22$ & $23-30$ & $31-40$ & $41-$ \\
\hline 174 & 109 & 36 & 9 & 109 & 87 & 58 & 49 & 21 & 4 \\
\hline
\end{tabular}

I acquired a total of 328 questionnaires in my hand to evaluate. Out of 328 teachers who filled out the questionnaire,

$11 \%$ of them were graduated from educational departments of universities, $88 \%$ of them from different departments, especially BBA.

$97 \%$ of them were local while the rest were foreign.

Table 2. Participants' Gender, Degree and Nationality

\begin{tabular}{|l|l|l|l|l|l|}
\hline \multicolumn{2}{|c|}{ Gender } & \multicolumn{2}{c|}{ Last Degree Received from } & \multicolumn{2}{c|}{ The teacher is } \\
\hline M & F & $\begin{array}{l}\text { Educational } \\
\text { Departments }\end{array}$ & Other & Local & Native \\
\hline 88 & 240 & 36 & 292 & 318 & 10 \\
\hline
\end{tabular}

\section{Results}

The language learning process has a noteworthy consequence on how novices are able to 
obtain the foreign language. As was presented, the approach of education for one's mother tongue can be implemented for foreign language learning. Principally, those who are dedicated themselves in the youngsters' learning process, initially, are their parents, and later their educators. Thus instructors ought to use unhurried approaches that parents commonly use quite instinctively to encourage a new learners' progress of a foreign language. Performing these policies and developing enthusiasm may support beginners overcome difficulties with foreign language acquisition.

Salem (2011) stated in his study that there are many academic and behavioral problems regarding students that face teacher in the classroom and has a direct impact on the teaching learning process such as: for getting school tools, frequent absence, lack of attention, hyperactivity, inappropriate talk in the classroom vandalism, disobedience, aggressiveness, refused to do tasks and school works.

I have divided the findings into four main categories after analyzing the closed-ended questionnaire. The four categories are School Administration, teacher, student and other. Charts are provided to display the questionnaire outcomes. Numbers are given as per number of participants.

\subsection{School Administration}

Problems of School Administration are;

\subsubsection{Lacking Administrators Having Education Background}

A school principal is the primary leader within the educational institute. A good leader always leads by example. A principal should be positive, enthusiastic, have their hand in the day to day activities of the school, and listen to what their constituents are saying.

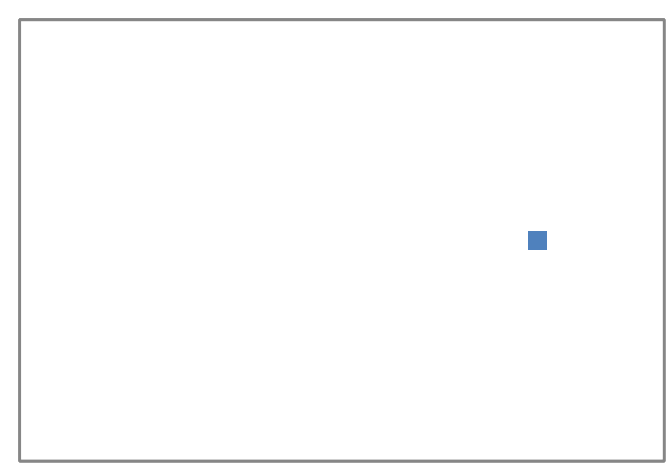
The problem here in Bangladesh is appointing, mostly, retired army officers as principal of the schools in order to maintain the discipline, however the chairman (owner) of the schools need to keep in mind that becoming a school principal requires passion for higher education in teaching and strong leadership skills. Principals serve as the leaders and supervisors of schools. They manage and assist teachers and all other staff.

\subsubsection{Not Having Admission Exam}

Admission exam questions are usually selected on the strength of applicants' earlier academic merits. Standardized entrance exams play a major role in the English Medium School admission process to take homogenously knowledgeable students in a class. Some schools have financial priorities rather than education, taking students without any admission exam, thus there is a knowledge difference in the class and teachers are having difficulties of English language teaching at English medium schools'

nistrators ize

er

ssion

I for

!ment. 
primary sections in Bangladesh. As we understand from the chart that, administrators have to consider admission exam in the decision for admitting a student and the judgment must be taken by the teachers, not by the admins. Predominantly in Grade 1, teachers suffer if the student were not ready during kindergarten for primary level in the case of lacking proper admission test system.

\subsubsection{Not Having Suspension \& Expulsion System}

In-school suspension and expulsion programs must be adopted in English Medium schools in order to gain constructive behaviour development among students. For parents, teachers and administrators, in-school suspension disciplinary option is a positive alternative to out-of-school suspensions since it permits students to stay in school and continue to learn while experiencing a consequence for misbehavior. Considering the financial issues, most of English medium schools do not have suspension system here in Bangladesh, so some students have behavioral problems and become corrupt role models for the virtuous students. It creates problems teaching English with irregular, inattentive, demotivated and unmindful students.

\subsubsection{The Problems of Resources}

The school administrator has to have proper resource for the students and the teachers. These are flashcards, encyclopedias, books, dictionaries and else. Lacking all these cause strategy difficulties especially for untrained teachers. At English Medium Schools in Bangladesh particularly, there shall be abundant resource since students learn a foreign language.

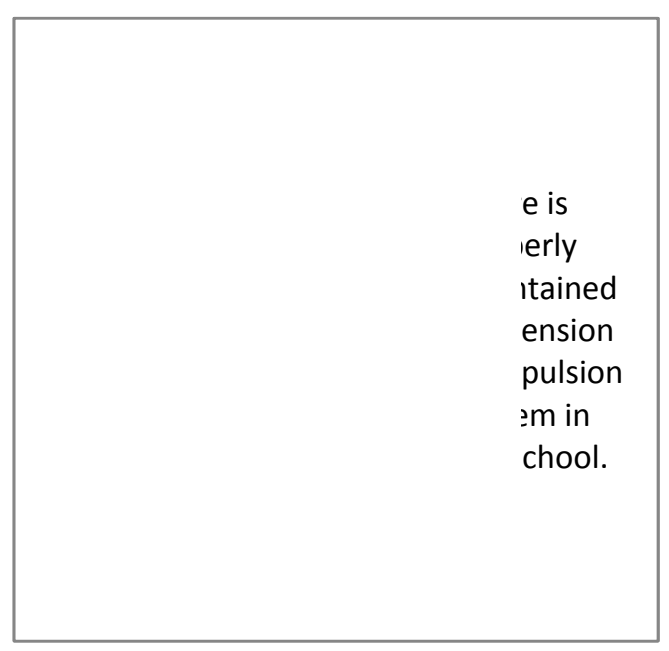

\subsubsection{Lacking Library}

Children and their teachers need library resources and the expertise of a librarian to succeed. School libraries help teachers teach children (Keith 2004). A school library is an academic resource center that supports school programs as well as the teaching and learning process. There must be well-designed library, which is both aesthetically appealing and contain an eclectic selection of relevant books. Walking through the library just opens up many kinds of opportunities to read and learn about many things. The school library is central to learning and plays a key role as a

\begin{tabular}{|l|l|}
\hline ink \\
re are \\
jurce \\
blems in \\
school. \\
\\
\hline \\
\hline \\
\\
\\
\\
have \\
per \\
ary in \\
school \\
i English \\
guage \\
:erials. \\
\\
\end{tabular}


place for encouraging innovation, curiosity, and problem solving, however what we see here in Bangladesh is a fewer number of libraries due to space problem and giving priority to have more classrooms. Another point is not arranging a budget by the school management to purchase books for the library. Insufficient libraries cause a lacking interest in books and consequently reading books go behind of technology, i.e. computer, iPad, mobile or else. Students lose time instead of reading books and developing new vocabulary, getting familiar with new structures and absorbing new phrasal for their enhanced future.

\subsubsection{Lacking Multimedia Room}

We should bring technology to the classroom because:

- Technology is not limited by the classroom walls.

- Technology does not know or care what the student's socioeconomic status may be, and thus helps to level the playing field for these students.

- Technology provides an equal opportunity for everyone to learn.

əve

$r$

nedia

in our

I with

$\mathrm{h}$

age

ials.

- Technology is more in tune with the way our students learn today.

- Technology is such a vast part of the real world that to limit its use in the classroom is to limit our students' ability to compete in the world.

About $98 \%$ of all incoming information to the brain comes through the senses. Incorporate the fact that over $87 \%$ of the learners in the class-room prefer to learn by visual and tactile means, and you have a methodology for failure if the primary methods of teaching are auditory. In Growing Up Digital (1998), Don Tapscott said that this "Net Generation" watches much less television than did its parents. The television is not interactive, and this generation prefers to be active participants in all that they do. Tapscott cited a 1997 survey by Teenage Research Unlimited, in which $80 \%$ of the teenagers polled said it is "in" to be online - right up there with dating and partying.

In order to have meaning to the learner in terms of retrieval, semantic information must have a connector. Try memorizing a long list of words and you will see what I mean. The brain was not created for memorizing meaningless information. If you try to memorize a long list of words, you will probably find yourself devising a plan to help you, such as creating acronyms or developing a story around the words to help you memorize them. We are giving the words a context or connection to help us remember. Contextual learning is stored in the episodic memory system, which is much better at remembering. 1 


\subsubsection{Playground}

Most of English Medium Schools in Bangladesh are located at a rented 'houses' which are not designed for schooling. Most of them do not have proper playground. Since the owners of schools are businessman and not educationist, they are uneager to have bigger buildings with appropriate-sized playground. Due to supply and demand ratio, they don't bother with a 'detail' like the playground. The population of Bangladesh is nearly 180 million and they provide students with a playground as inadequate

\begin{tabular}{|l|}
\hline \\
\\
here is \\
cell- \\
esigned \\
layground \\
i my \\
shool. \\
\\
\\
\end{tabular}
as a basement.

\subsection{Teachers}

There are some difficulties of English language teaching in English Medium schools' primary sections in Bangladesh and schools can help the teachers improve their skills at a more efficient pace, thereby keeping them in the profession and raising student achievement. ${ }^{2}$

\subsubsection{Struggling with Classroom Management}

The biggest challenge that surfaces for the teachers is classroom management. A separate survey of 500 teachers found that teachers with three years or fewer on the job were more than twice as likely as teachers with more experience (19 percent versus 7 percent) to say that student behavior was a problem in their classrooms (Norris, 2003). The difficulty related with classroom management faced by the teachers who teach at English Medium Schools' Primary Sections in Bangladesh is to be unable to control the class and having exertion.

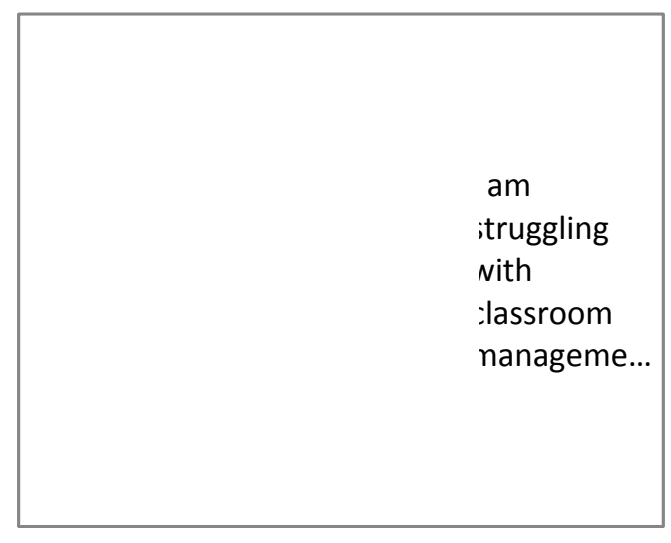

\subsubsection{Underpaid Teachers}

Schools are deeply concerned with the quality of their teachers, but quality is difficult to discern when hiring a new teacher. Graduating from a good college and achieving high scores on tests of verbal aptitude are reasonable, though highly imperfect, indicators of teacher quality. There are schools which they give really inadequate salaries and it effects the teacher's 'm 2 'nderpaid. motivation.

The chart explicitly indicates the dissatisfaction of the teachers in English Medium schools. 


\subsubsection{Untrained Teachers}

Education is very important for an individual's success in life. It provides pupils with those skills that prepare them physically, mentally and socially for professional employment in later life. It is considered as a foundation of society, which brings sound economy, social prosperity and political stability. Although there is a great role of teachers in trained. promoting education, but the efficiency and effectiveness of teachers depends upon the teacher's training. If the teachers are well educated and if they are intellectually alive and take keen interest in their job, then only, success can be ensured. On the other hand, if they lack training in education and if they cannot give their heart to their profession, the system is destined to fail. The teachers are dynamic force of school. A School without teacher is just like a body without soul. It requires teachers to use the latest methodologies and techniques and if most teachers know little or nothing about the curriculum, there will be a lot of problems for students to understand concepts introduced by the untrained teachers. The main problem in Bangladesh is that there is no regulation for English Medium Schools by the Government of Bangladesh. English medium schools are controlled by British Council and they primarily consider number of applicant to their institute for monetary benefits.

Anybody can be a teacher at English Medium Schools in Bangladesh. Since 2005, I have been interviewing the candidates to be teacher at the school where I serve. I have personally heard dozens of astonishing answers for the question of 'Why do you want to be English Language teacher? '. Some of the answers are;

- I am a housewife and I have time ...

- I have graduation from BBA, but I think I can.

- During my studies in a Bangla Medium School, my English was good..

- I have master degree. I can.. (those who have studied for one year masters in ELT or English, however having Bengali Medium background, thus familiarity with English is one year only)

- I was at an office working as an officer; but as a lady, working at a school is much better since it is having less working hours. I do not have experience but I can..

\subsection{Student}

There are different matters with students. The difficulties are presented as;

\subsubsection{Student's Mental Abilities}

Teachers may face a group of students who suffer from the slowdown in the classroom, faltering and failure in learning and they need more time than their peers need to 
accomplish any learning task. Such students are characterized by a number of characteristics, including problems of language, oral expression, and inability to pay attention, memory problems and the dispersal of attention. In addition, teachers encounter another kind of problem in the classroom of gifted students. According to the chart we see that minority of the teachers think that student's mental abilities are playing an important role in teaching English Language.

\subsubsection{Misleading House Tutors}

A house tutor is a person who helps the children at home for their homework. They are mostly students and may be from English Medium School or Bangla Medium School. The main problem here is the house tutor, who is unaware of the system of teaching of the school, (s)he will mislead the student and the student will have confusion in study. Whether or not tutoring is popular, the motivation for directing students to tutoring has not always been wise, which

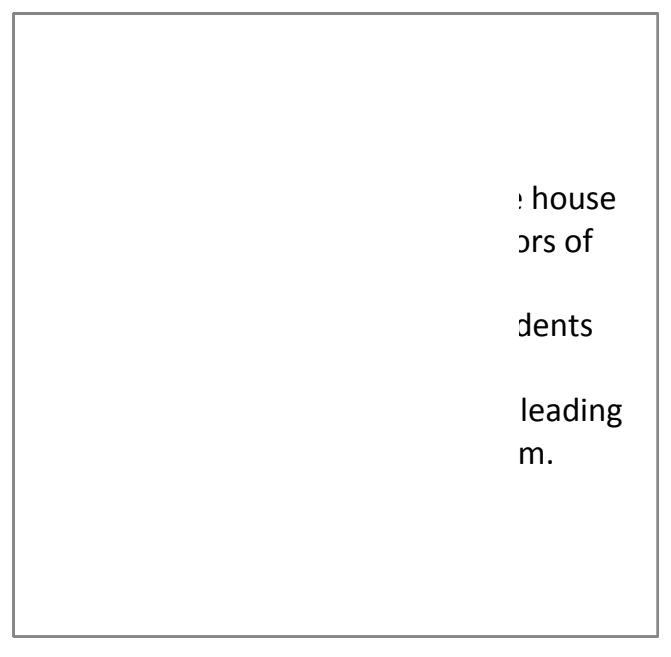
is why the tendency to tutor has come in for rightly deserved criticism. Some children are being driven toward tutoring out of a mistaken belief that it is always valuable - that it is simply another way to enrich the educational experience of a child, as if it were a guaranteed means to ratchet up the quality of education for any child.

\section{4 Family}

There are different matters with students. The difficulties are presented as;

\subsubsection{Overprotective Attitude of the Parents}

The overprotective attitude of parents nowadays is inadvertently detrimental. Parents should be teaching their children to be self-sufficient, well rounded members of society. Overprotective attitude of the parents affect the teachers and the parents create problems. Having a couple of cleaners and helping hands, some drivers and more, hamper the child's

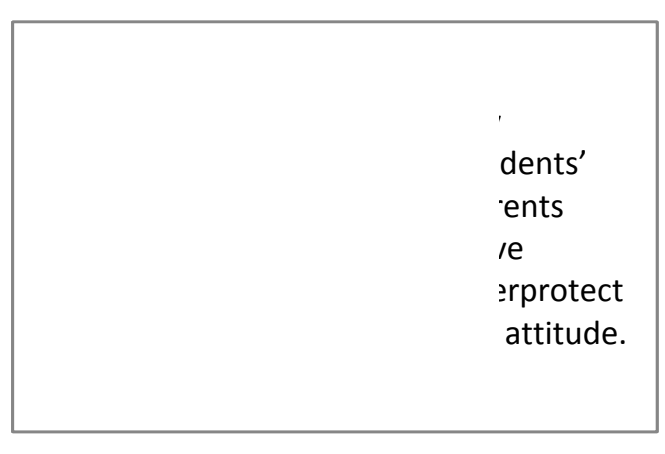
development of self-confidence.

\subsubsection{Criticizing the Teachers in Front of Students}

Parents can have opinions and suggestions but they can't make demands. It seems as though some parents think they are entitled to have their ideas put into place simply because they exist.

Criticizing teachers and schools in front of children may confuse them. Even very young children can pick up the worry, frustration, or disdain that parents may feel concerning their children's school experiences. In the case of the youngest children, it is not unusual for them 
to attribute heroic qualities to their teachers and hearing criticism may put them in a bind over divided loyalties. In the case of older children, such criticism may foster rudeness or defiance with their teachers; besides causing confusion, criticizing teachers in front of children is not conducive to solving the underlying problem.

According to the chart above, we see that the teachers do not feel comfortable to be criticized in front of the students and it impairs the relations.

\subsubsection{Family Background}

The family lifestyle, environment and spoken language will put its mark on improvement of English for the students while language is the bridge between home and school. Among the most important tasks of the first five years of life is the development of language. Children's language ability affects learning and development in all areas. There are some English Medium Schools which take their students after examining the students arranging interviews with specifically the mother. They consider the mothers as those who are helping hands in students' study. If the mothers are lacking English

ents'

nts

ize me

ont of

ents.

ly ground sffect glish uage ing. competency, those schools do not take the students even if they obtain the best scores in the placement exams.

\section{Conclusion}

To conclude, the importance of teaching English language teaching andl learning has been acknowledged for various reasons and a great deal of attention is given to all the skills of foreign language teaching.

Education is more than reading, writing, and arithmetic. It is one of the most important investments a country can make in its people and its future and is critical to reducing poverty and inequality. If all students in low income countries left school with basic reading skills a close approximation of 180 million people could be elevated out of poverty. Generally, at the start of a very young age, children learn to develop and use their mental, moral and physical abilities, which they acquire through various types of education. Education is commonly referred to as the process of learning and obtaining knowledge at school, in a form of formal education. Girls and boys, who learn to read, write and count will provide a better future for their families and countries. With improved education, so many other areas are positively affected. In short, education has the power to significantly create vast improvements throughout the world. 


\section{Al Macrothink}

International Journal of English Language Education

ISSN 2325-0887

2016, Vol. 4, No. 1

Teaching any foreign language is not always a pleasurable experience in the sense that the whole process of foreign language teaching and learning is often considered being very difficult and uninteresting. In such situation, the teaching methodology, adopted by the foreign language teacher, the material, selected for teaching and learning the language skills, and various motivational and learning strategies play a very crucial role in deciding the success or failure of foreign language teaching and learning.

English may not be the most spoken language in the world, but it is the official language in a large number of countries. It is estimated that the number of people in the world that use in English to communicate on a regular basis is 2 billion. English is the dominant language of business and it has become almost a necessity for people to speak English if they are to enter a global workforce, research from all over the world shows that cross-border business communication is most often conducted in English. Its importance in the global market place therefore cannot be understated, learning English can drastically alter one's life. Many of the world's renowned films, books and music are published and produced in English. Therefore by learning English one will have access to a great wealth of entertainment and will be able to have a greater cultural understanding. Most of the content produced on the internet $(50 \%)$ is in English. Therefore knowing English will allow one access to an incredible amount of information which may not be otherwise available! ${ }^{3}$

There are some difficulties of teaching English language at English medium schools' primary sections in Bangladesh among Bangladeshi students. These difficulties were categorized under four sections; school administration, teachers, students and parents. To overcome the difficulties, the concerned authorities shall take actions to have the benefits to have a fountain of golden generations in Bangladesh.

There are certain limitations to this study. The researcher could distribute more questionnaires among more teachers. We could have much more reliable result if we had further number of participant. The study has applied to three cities' teachers. We could go to some other cities especially to the cities at the Indian border side.

In this study, we have the implications of findings and the main predicament is lacking dedicated teachers and dedicated administrators. Problems with school administration, teachers, students and parents can easily be solved is this primary problem is alleviated. This can be a further study by explicitly elucidating the importance of dedication in education.

\section{Notes}

1. URL http://www.corwin.com/upm-data/6635 tileston 9 ch_1.pdf

2. URL

$<$ http://www.ascd.org/publications/educational-leadership/may12/vol69/num08/NewTeachers-Face-Three-Common-Challenges.aspx $>$

3. URL $<\underline{\text { http://www.esoe.co.uk/blog/4-reasons-why-learning-english-is-so-important/ }}$ 


\section{Macrothink}

\section{References}

Ahmed, M., \& Nath, S. R. (2005). Quality with Equity: The Primary Education Agenda. Dhaka: Campaign for Popular Education.

Ainy, S. (2001). English Language Teaching in Bangladesh Open University: Changing Scenario. Journal of Distance Education. Directorate of Distance Education, University of Jammu. Retrieved January 10, 2012, from http://cemca.org/disted/Ainy-salma-o296.pdf

Banu, L. F. A. (2009). Problems and Misconceptions Facing the Primary Language Education in Bangladesh: An Analysis of Curricular and Pedagogic Practices. BRAC University Journal. Institute of Educational Development, BRAC University (IED - BU). 1: 1-10.

Borg, S. (2003). Teacher cognition in language teaching: a review of research on what language teachers think, know, believe, and do. Language Teaching 36, 2 April 2003, 81 109.

Cajkler, W., \& Addelman, R. (2000). The Practice of foreign language teaching. London: David Fulton.

Clegg, J., \& Afitska, O. (2011). Teaching and learning in two languages in African classrooms. Comparative Education, 47(1), 61-77.

Corder, S. P. (1967). The significance of learners' errors. International Review of Applied Linguistics.

Doyle, W. (1986). Classroom organization and management. In M. C. Wittrock (Ed.). Handbook of research on teaching (3rd ed.). New York: Macmillan.

Dörnyei, Z. (2001). Motivational strategies in the language classroom. Cambridge: Cambridge University Press.

Driscoll, P., \& Frost, D. (1999). Teaching of Modern foreign Languages in Primary schools. London: Routledge.

Éireann. (2004), Language in the Primary School, Irish National Teachers' Organization, INTO Publication

Ellis, R. (1994). The study of second language acquisition. Oxford: OUP

Fisher, C., \& Jeffrey, D. L. (1986) Edge: Constructing a Questionnaire. Ohio State University: Ohio Cooperative Extension Service.

Freiberg, H. J. (Ed.). (1999). Beyond behaviorism: changing the classroom management paradigm. Boston: Allyn \& Bacon

Fry, S. W. (2007). First-year teachers and induction support: Ups, downs, and in-betweens. The Qualitative Report, 12(2), 216-237.

Ganakumaran, S., \& Shahizah, I. H. \& Koo, Y. L. (2003). Pedagogical implications of the incorporation of the Literature Component in the Malaysian ESL syllabus, in Ganakumaran 


\section{Macrothink}

International Journal of English Language Education

ISSN 2325-0887

2016, Vol. 4, No. 1

Subramaniam (Ed), Teaching Literature in ESL/EFL Contexts. (pp 62-187). Petaling Jaya: Sasbadi.

Glynis, R. (1999). Games and songs for teaching modern foreign languages to young children, Routledge

Gorman, T. P. (1968). Bilingualism in the educational system of Kenya. Comparative Education, 4(3), 213-221.

Hasan, M. K. (2004). A Linguistic Study of English Language Curriculum at the Secondary Level in Bangladesh - A Communicative Approach to Curriculum Development. Language in India, 4: 8. Retrieved December 12, 2011, Retrieved from www.languageinindia.com/august2004/has andissertation1.html

Karim, K. M. R. (2004). Teachers' perceptions, attitudes and expectations about Communicative Language Teaching (CLT) in post-secondary education in Bangladesh. A Thesis for the Degree of Master of Arts. Department of Curriculum and Instruction, University of Victoria. Retrieved December 16, 2011, from dspace.library.uvic.ca:8080/bitstream/hand le/1828/560/karim_2004.pdf?sequence=1

Keith, C. L. (2004). The impact of school media centers on academic achievements.

Kizildag, A. (2009). International Electronic Journal of Elementary Education Vol.1, Issue 3, June.

Krinshaswamy, N. \& Sriraman, T. (1984). English Teaching in India. Madras: T.R. Publications.

Lewen, T. (2005). Problems faced by primary school teachers in teaching literature component: The short story.

Marshall, M. G. (1998). Questionnaire Design Asking Questions with a Purpose, Program Development \& Evaluation of The Texas A\&M University System

Neuman, W. L. (2002). Qualitative and quantitative approaches in Social Research Methods, 3rd edn, Allyn and Bacon, NY, Chapter 7, p. 131-175 \& Chapter 10, pp. 233-254.

Norris, J. M., \& Ortega, L. (2000). Effectiveness of L2 instruction: A research synthesis and quantitative meta-analysis. Language Learning, 50, 417-528.

Rohs, F. R. (1985). Questionnaire Construction. Athens, GA: Cooperative Extension Service.

Sadek, M. A. (2002). The Problems of English Language Teaching at Primary Level in Rural School of Bangladesh. Unpublished Master's Thesis, IER, University of Dhaka.

Salant, P., \& Don, D. (1994). How to Conduct Your Own Survey. New York. John Wiley \& Sons, Inc.

Salem, M. (2011). Int J Edu Sci, 3(1), 37-48

Sharpe, K. (2001). Modern Foreign Languages in the Primary Schools. London: Kogan Page 


\section{Macrothink}

International Journal of English Language Education

ISSN 2325-0887

2016, Vol. 4, No. 1

Shukla, S. (2008). Activity oriented curriculum and pedagogy. Speech provided in workshop on April 3 - 4, 2008. Institute of Educational Development, BRAC University, Dhaka.

Shin, S., \& Koh, M. S. (2007). A cross-cultural study of teachers' beliefs and strategies on classroom behavior management in urban American and Korean school systems. Education and Urban Society, 39(2), 286-309.

Sudman, S., \& Norman, M. B. (1982). Asking Questions: A Practical Guide to Questionnaire Design. San Francisco: Jossey-Bass Publishers,

Tapscott, D. (1998). Growing Up Digital: The Rise of the Net Generation. New York: McGraw Hill

Warwick, D. P., \& Lenninger, C. A. (1975). The Sample Survey: Theory and Practice, McGraw Hill Inc, USA

Winke, P. M. (2005). Promoting Motivation in the Foreign Language Classroom. Clear News, 9(2), 1-6.

\section{Appendix A}

\section{Survey}

Thank you very much for accepting participating in this survey which will be used in my master dissertation. Personal information, name of school or coaching center etc. will not be stated in the dissertation. Name of the cities where the students are going to participate will be revealed only. Please read the statement below and put a tick mark in the appropriate option in order to show how far you agreed or disagreed with each statement. There is a grid consisting of five columns: for 'strongly agree', 'agree', 'uncertain', 'disagree` and 'strongly agree`. Please choose the one which suitable for you.

\begin{tabular}{|c|c|c|c|c|c|c|}
\hline & & 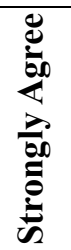 & 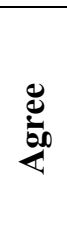 & & 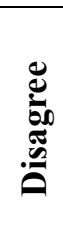 & 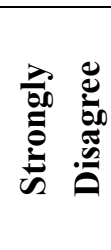 \\
\hline $\mathbf{1}$ & I am burdened by curricular freedom. & & & & & \\
\hline 2 & My students' parents criticize me in front of my students. & & & & & \\
\hline 3 & $\begin{array}{l}\text { Family background has effect in English Language } \\
\text { teaching. }\end{array}$ & & & & & \\
\hline 4 & $\begin{array}{l}\text { The administrators in my school have background in } \\
\text { education. }\end{array}$ & & & & & \\
\hline 5 & We have proper library in our school with English & & & & & \\
\hline
\end{tabular}




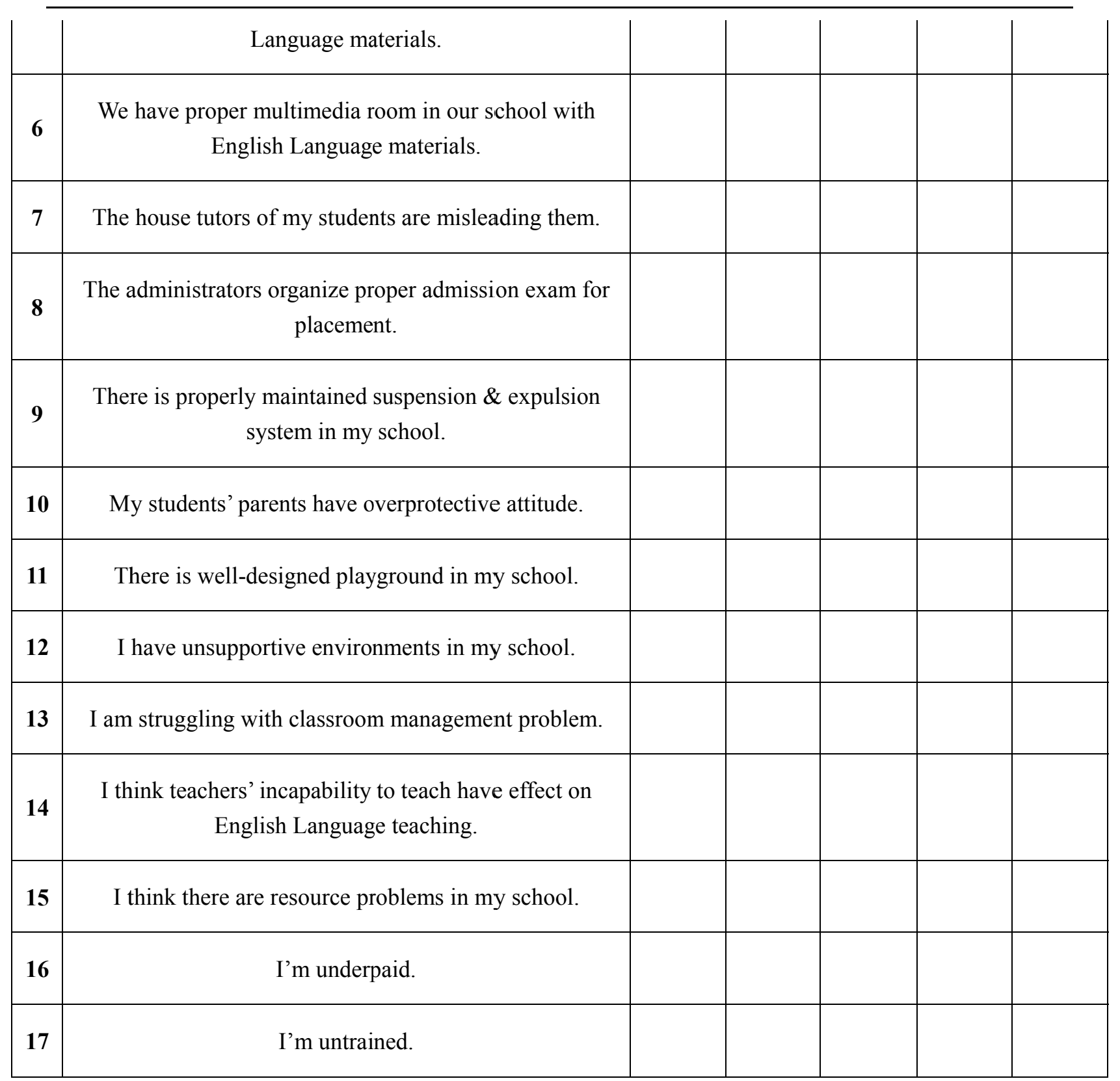

\section{Appendix B}

\section{Cover Letter}

Date:

TO: The Principal / Director, 
Dear Sir / Madam,

I, Ismail Akbas, seek the cooperation of your school / coaching center authority to select some students for conducting a small scale research for the purpose of data collection for my research to be submitted to International Journal of English Language Education, USA. You're requested to carry out the survey. My study is about Difficulties of English Language Teaching at English Medium Schools' Primary Sections in Bangladesh. I ensure that all the personal information will be kept anonymous.

I'm hopeful enough that you'll accept the proposal and make all the necessary arrangements to carry out my research.

Yours truly,

Ismail Akbas

Date / Signature

\section{Copyright Disclaimer}

Copyright for this article is retained by the author(s), with first publication rights granted to the journal.

This is an open-access article distributed under the terms and conditions of the Creative Commons Attribution license (http://creativecommons.org/licenses/by/3.0/). 